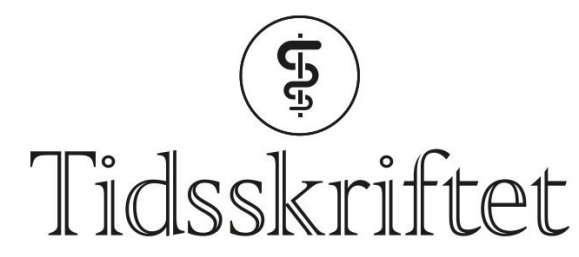

DEN NORSKE LEGEFORENING

\title{
En ytterst tåpelig dans
}

TIDLIGERE I TIDSSKRIFTET

\section{JULIE DIDRIKSEN}

Tidsskriftet

Pardansen tango oppstod på slutten av 18oo-tallet i de fattige strøkene langs elven Río de la Plata på grensen mellom Argentina og Uruguay. Ordet ble angivelig tidligere brukt om musikalske sammenkomster blant slaver, og dansestilen ble gjerne praktisert på bordeller og andre steder med et litt frynsete rykte. Dette bidro muligens til at dansen ble litt sterk kost for enkelte. Den som skrev den følgende beskjeden i Tidsskriftets utgave nr. 15/1914 virket i alle fall ikke spesielt imponert over den (Tidsskr Nor Lægeforen 1914; 34: 1095).

«Tango-syken» er en ganske ny sygdom, som opstaar efter overdreven tangodansing, - den nye, efter manges mening yderst taabelige dans.
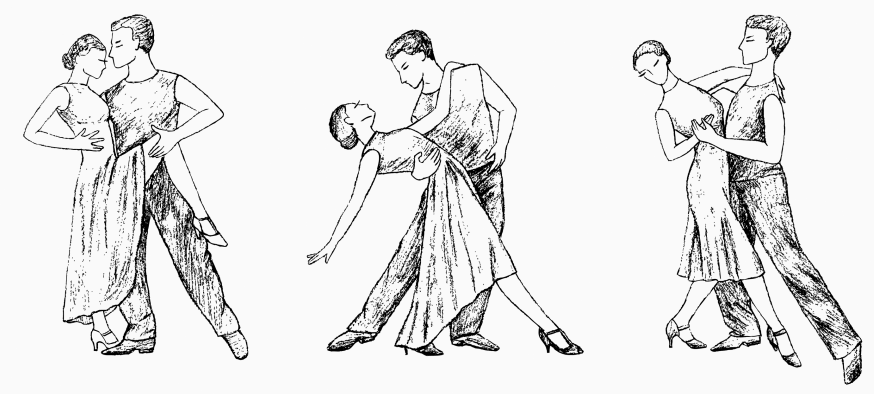

Illustrasjon: mubai/iStock

Sygdommen er beskrevet av dr. Böhme i «Klinisch-therapeutisches Wochenschr.» og forekommer hos dansere og danserinder, som under utførelsen av «tangoens» mange komplicerte figurer har overanstrengt fotens strækkemuskler, saa der er fremkommet en smertefuld betændelse i musklerne.

Publisert: 26. april 2019. Tidsskr Nor Legeforen. DOI: 10.4045/tidsskr.18.0975

(C) Tidsskrift for Den norske legeforening 2020. Lastet ned fra tidsskriftet.no 